\title{
Livestock Grazing and Wildlife: Developing Compatibilities
}

\author{
Martin Vavra \\ Author is Professor of Rangeland Resources and Superintendent of Eastern Oregon Agricultural Research Center, \\ Oregon State University, Burns, OR 97720 and Range Scientist, Pacific Northwest (PNW) Research Station, \\ Forest Service, Forestry and Range Sciences Laboratory, La Grande, OR 97850.
}

\begin{abstract}
Livestock grazing has been considered detrimental to wildlife habitat. Managed grazing programs, however, have the potential to maintain habitat diversity and quality. In cases in which single-species management predominates (sage-grouse [Centrocercus urophasianus] or elk [Cervus elaphus nelsoni] winter range), grazing systems specific to species' needs can be implemented. Managed livestock grazing can have 4 general impacts on vegetation: 1) alter the composition of the plant community, 2) increase the productivity of selected species, 3) increase the nutritive quality of the forage, and 4) increase the diversity of the habitat by altering its structure. Implementing a grazing management plan to enhance wildlife habitat requires an interdisciplinary approach. Knowledge of plant community dynamics, habitat requirements of affected wildlife species, and potential effects on the livestock used are basic to successful system design. However, any habitat change made for a featured species may create adverse, neutral, or beneficial changes for other species. Management actions, other than development of a grazing system, are often required for habitat manipulations to be successful. More research efforts are needed to understand complementary grazing systems on a landscape scale.
\end{abstract}

\section{Resumen}

El apacentamiento del ganado ha sido considerado como detrimental para el hábitat de la fauna silvestre, sin embargo, programas de apacentamiento bien manejados tienen el potencial para mantener la diversidad y calidad del hábitat. En casos donde el manejo de una sola especie predomina, ("sage-grouse" [Centrocercus urophasianus], alce [Cervus elaphus nelsoni] winter range) se pueden implementar sistemas de apacentamiento específicos para las necesidades de la especie. Manejando el apacentamiento del ganado pueden tener cuatro impactos generales sobre la vegetación: 1) altera la composición de la comunidad vegetal, 2) incrementa la productividad de las especies seleccionadas, 3 ) incrementa la calidad nutritiva del forraje y 4) incrementa la diversidad del hábitat al alterar su estructura. Implementar un plan de manejo de apacentamiento para mejorar el hábitat de la fauna silvestre requiere trabajo interdisciplinario. El conocimiento de las dinámicas de la comunidad vegetal, los requerimientos de hábitat de las especies de fauna silvestre afectadas y los impactos potenciales sobre el ganado utilizado son básicos para el diseño exitoso del sistema. Sin embargo, cualquier cambio hecho para una especie en particular puede crear cambios adversos, neutros o benéficos para otras especies. Otras acciones de manejo diferentes al desarrollo de un sistema de apacentamiento a menudo son requeridas para que la manipulación del hábitat sea exitosa. Se necesitan mas esfuerzos de investigación para entender los sistemas de apacentamiento complementarios a una escala de paisaje.

Key Words: cattle, facilitation, herbivory, deer, elk

\section{INTRODUCTION}

The western livestock industry once viewed sustainability as generating the same amount of animal product year after year without degrading the grazing resource (Vavra 1998). Today the definition of sustainability is much more complex (Vavra 1996). Grazing management systems must consider a wide array of other values including watershed quality, aesthetics, and biodiversity. There is a need to develop grazing management systems that are ecologically responsible and that can be a tool for conservation (Curtin 1994). The effects of poor grazing management are well documented. Fleischner (1994) identified the ecological costs of livestock grazing as the loss of biodiversity; reduced population densities of a wide variety of

Correspondence: Dr Martin Vavra, PNW Research Station, Forestry and Range Sciences Laboratory, 1401 Gekeler Lane, La Grande, OR 97850. Email: mvavra@fs.fed.us

Manuscript received 15 March 2003; manuscript accepted 14 May 2004 taxa; disrupted ecosystem functions, including nutrient cycling and succession; changes in community organization; and changes in the physical characteristics of both aquatic and terrestrial habitats. Fleischner (1994) described livestock grazing as the most pervasive land use in North America and the most important factor limiting wildlife production in the West. Jensen (2001) stated that scientists and environmentalists have criticized livestock grazing for causing a host of ecological ills. There is a need to develop new approaches to grazing management that are sustainable and based on ecological soundness.

In this article, I describe the potential for manipulating wildlife habitat via specialized livestock grazing systems and challenge scientists and managers to explore these principles in related research and management.

\section{RATIONALE}

Severson and Urness (1994) provided insights into the potential for various tools for enhancing wildlife habitat. The authors 
quoted Leopold (1933): "Cover is controlled by controlling plant succession in the right direction at the right time and place. Cow, plow, axe, and fire reverse succession. Fencing, firesuppression, and planting advance it." Severson and Urness (1994) noted that managed timber harvest, prescribed fire, and mechanical treatments (plowing) have evolved into recognized and accepted tools, but livestock grazing is still largely regarded as detrimental to wildlife habitat. Knopf (1996) provided insights into this dichotomy. Scientific evidence on the effects of livestock grazing on wildlife habitat has often been flawed by 1) poor study design, 2) abusively grazed sites carelessly construed to represent proper range management, and 3) investigator advocacy for a fisheries or wildlife resource. Knopf (1996) went on to say that most of the literature on this topic is dominated by papers not subject to critical review by peers.

Anderson and Scherzinger (1975) provided the seminal article for grazing management as a tool for wildlife habitat improvement. In 1975, however, wildlife was generally interpreted to be those species that had value for consumptive use (hunting). Today, wildlife is considered in a much broader context and usually is viewed in terms of biodiversity. Therefore, attempts to develop grazing management systems for improving wildlife habitat cannot be applied in broad-brush or simplistic fashion such as providing forage for game animals. The real challenge to managers is to develop grazing systems that do not degrade, or in some cases, that provide recovery of the biotic and abiotic components of the landscape in question. Nevertheless, there are species of interest that require that specific habitat components be preserved or restored and that require grazing management practices be specific to that organism.

The desert tortoise (Gopherus agassizii) and sage-grouse (Centrocercus urophasianus) provide current examples of species of interest. Sage-grouse have become the center of controversy in regard to grazing on western rangelands. At the Western States Sage-Grouse Workshop, Hess (1975) posed the question of the possibility of grazing management being applied to maintain habitat conditions for sage-grouse; most participants felt it could be done, but no one was sure how. Little has changed in 28 years. However, grazing management for the improvement of forage quality for sage-grouse appears possible. For some time, forbs have been known to be important dietary constituents for sage-grouse (Peterson 1970). Simply, grazing management that sets back succession should provide improved forage for sage-grouse if the grazing treatment is intermittent so forbs are either not eaten by livestock or allowed to regrow. Desert tortoises require high-quality vegetation during their months of activity: March to June and September (Huxtable 1992). Cattle (Bos taurus) grazing in tortoise habitat should be manipulated so that the forage available to tortoises provides adequate nutrition during their time of activity.

\section{APPROACH}

The problem with initiating compatible grazing management is overcoming biases formed from past grazing abuses (Vavra 1998) and current antigrazing literature (Fleischner 1994). It can be difficult to convince land management agencies that managed livestock grazing can actually be used as a constructive tool or be, at least, a benign event. Compounding the problem is the continuing degradation of wildlife habitat by various aspects of civilization. Today, wildlife in the western United States exists in increasingly fragmented, incomplete, and compressed habitats (Vavra and Sheehy 1996; Wisdom and Thomas 1996). Identification of critical habitat factors that are limiting is often more art than science because research data on the species of interest is not available. Until recently, there was little interest in many species now considered "of interest." Research funding is, generally, difficult to obtain for the study of noncharismatic species, such as spotted frogs (Rana pretiosa). Other species pose challenges to scientists because they are landscape-scale organisms (sage-grouse) that migrate several miles through elevation and plant community gradients. Habitat requirements for an individual species may also vary seasonally; nesting, fawning, feeding, security, thermal regulatory, and breeding habitats serve as examples. Standing vegetation structure (ungrazed or lightly grazed areas) offers important nesting cover for ground-nesting birds, but those same birds may need grazed areas with an abundance of forbs or succulent grasses for feeding sites.

In the West, most plant communities are disturbance based. They are dynamic, and habitats present today may not exist in the future because of successional progression (increasing shrub/tree canopies or forb- to grass-dominated); the occurrence of a disturbance event (fire); or changing climate (Jensen 2001). This consideration must be built into grazing programs and associated management (prescribed fire, logging).

Once the desired habitats and the successional states of the landscape are identified, then a management plan can be developed to provide a trajectory in the desired direction. The key, at this point, is understanding the effects of livestock herbivory on plant communities. Ungulates are important agents of environmental change, acting to create spatial heterogeneity, to accelerate successional processes, and to control switching between alternative states (Hobbs 1996). Augustine and McNaughton (1998) present information that the effects ungulates have on plant communities depend on the balance between feeding selectivity of herbivores (which determines the degree to which different plant species experience different levels of tissue loss) and differences among plant species in their ability to recover from tissue loss. That knowledge can then be put to use to develop grazing systems that 1) alter the composition of the vegetation, 2) increase productivity of selected species, 3 ) increase the nutritive quality of the forage, and 4) increase the diversity of the habitat by altering its structure (Severson and Urness 1994). Payne and Bryant (1994) provide an expanded and more specific list of grazing effects on vegetation.

\section{Composition Change and Increased Productivity}

Competition theory suggests that in a landscape inhabited by herbivores that prefer one class of forage (grass, forb, or shrub), that preferred forage will, through defoliation, be less competitive than those species not grazed. Altered plant species composition is a general feature of plant-ungulate interaction that extends across biomes (Augustine and McNaughton 1998). Mule deer (Odocoileus hemionus hemionus) winter range provides the classic example where bitterbrush (Purshia tridentata Pursh DC.) has often declined because of prolonged fall, 
winter, and early spring use by deer whereas perennial grass cover has increased (Smith 1949; Urness 1990). Most contemporary livestock management systems are designed to advance succession, which usually enhances native perennial grasses and results in a decline in forb abundance. If an increase in the forb or shrub component is a management goal, then a properly timed entry with cattle will facilitate a change in the competitive relationship between grasses and forbs or shrubs.

Neal (1982) suggested periodic, heavy, spring use of cattle on deer winter ranges to enhance shrub production and seedling establishment, suggesting that the heavy use occur at 15to 20-year intervals. This strategy would reduce bunchgrass composition, with the exception of Sandberg's bluegrass (Poa sandbergii Vasey), which is important to the spring forage of mule deer. Moderate grazing would occur during the interim periods. Ganskopp et al. (1999) were successful in demonstrating that moderate, early-season cattle grazing improved both the height and volume of bitterbrush plants compared with those in ungrazed pastures. Ganskopp et al. (1999) also noted, as have others (Smith and Doell 1968; Lesperance et al. 1970), that once grasses start to senesce, cattle increase their consumption of bitterbrush. Jensen et al. (1972) used sheep (Ovis aries) and Reiner and Urness (1982) used horses (Equus caballas) to accomplish the same goal with bitterbrush in Utah. Livestock grazing can be effectively used as a tool to accomplish maintenance or improvement of the shrub component of plant communities.

Can a similar system be used to improve foraging habitat for sage-grouse? Forbs are important constituents of sage-grouse diets and are particularly critical during brooding and rearing. As succession progresses, perennial grasses increase with a concomitant decrease in the forb component. Judicious livestock management could cause a response in forbs similar to that noted for bitterbrush. Evans (1986) found that this was possible in northern Nevada meadows. Grazed meadows, where forbs had the opportunity to regrow, were more attractive to sagegrouse than were ungrazed meadows. In this regard, an important question surfaces: Is range management that advances succession (increasing the perennial grass component) detrimental to the nutritional well-being of sage-grouse?

\section{Improved Nutritional Quality}

Improving nutritional quality of forage can be accomplished in 2 ways: directly, by spring defoliation that initiates regrowth of superior quality when compared with ungrazed mature vegetation; and indirectly, by removing standing litter and increasing the availability of fall regrowth or new, spring growth. Improving nutritional quality of forage for elk (Cervus elaphus nelsoni) in the western United States has probably received the most grazing-system research and management attention (Anderson and Scherzinger 1975; Frisina and Morin 1991; Frisina 1992; Vavra and Sheehy 1996). Hyder and Sneva (1963) first proposed a spring grazing treatment to provide high-quality regrowth for fall use when previously ungrazed, dormant plants did not meet nutritive requirements for cattle. Anderson and Scherzinger (1975) provide this hypothesis of grazing effects on nutritional quality of forage: Properly timed grazing in the spring during the active growth stage of bunchgrasses delays reproductive efforts and maturity of the plants. Removing the current year's growth at the boot stage of phenology allows the plant to regrow. The regrowth is interrupted by soil moisture depletion that causes the plant to terminate physiological processes and not complete the reproductive cycle. The plant does not translocate nutrients to the roots, so nutrients are fixed in the aboveground parts. This provides high-quality elk forage. Timing of cattle removal is critical because sufficient soil moisture must remain to provide regrowth. Frisina and Morin (1991) and Frisina (1992) provide case histories of application with a rest-rotation grazing system. Rest-rotation provided 1) high-quality, winter forage for elk through the aforementioned conditioning process, 2) removal of mature vegetation, increasing the availability of regrowth, (3) current-year growth for winter feed in the rested pasture, and 4) maintenance of plant vigor through rest.

In northern Nevada, on meadows important to sage-grouse in summer, Evans (1986) demonstrated that timed cattle grazing provided regrowth of forbs that attracted sage-grouse. The availability of nutritious forb regrowth continued throughout the summer on the grazed sectors, whereas on the ungrazed meadows, forbs matured and sage-grouse elected to forage elsewhere.

Research verification of these applied practices has been mixed (Vavra and Sheehy 1996). Bryant (1993) and Westenskow-Wall et al. (1994) applied spring clipping to bluebunch wheatgrass (Agropyron spicatum [Pursh] Scribn. \& Smith) plants during the preboot stage. Subsequent nutritive value of the regrowth was not substantially enhanced over nonclipped plants. Pitt (1986) reported an improvement in nutritive quality of clipped, boot-stage plants over those not clipped but reported that forage quantity was compromised. Ganskopp (1998) periodically defoliated Thurber's needlegrass (Stipa thurberiana Piper) plants in southeastern Oregon, observed subsequent biomass accumulations, and then analyzed their nutritive quality. Forage quality was improved by the regrowth subsequent to clipping, but as clipping date advanced, regrowth quantity diminished. He cautioned that the timing of grazing was critical to providing both adequate quality and quantity of regrowth. In dry years, regrowth forage production might be seriously curtailed.

Indirect improvement of forage quality occurs when a grazing treatment is used to remove standing, mature vegetation that impedes the ability of an herbivore to access new spring growth or fall regrowth. Ganskopp et al. (1992) found that the presence of cured stems within new green growth decreased the probability of that plant being grazed by $30 \%-35 \%$. The removal of dormant vegetation through winter use by cattle resulted in greater biomass and availability of green grass in spring than that in ungrazed areas (Gordon 1988). Rhodes and Sharrow (1990) found that controlled sheep grazing on forest plantations resulted in initiation of spring growth earlier than in ungrazed areas, thereby providing high-quality forage for deer and elk at a physiologically critical time.

Vavra and Sheehy (1996) described a rest-rotation system that provided an array of forage available to wintering elk. In the system described, one pasture was grazed early in the boot stage of phenology. Regrowth from this pasture provided highquality material as previously described. The second pasture entry by cattle removed most of the current year's growth but provided for maximizing availability of any fall regrowth or 
new growth the following spring. The rested pasture recovered vigor during the growing season and furnished large quantities of current-year growth for wintering elk. In this system, both direct and indirect mechanisms of improving nutritional quality were in effect. The 2 grazed pastures provided high-quality regrowth in fall and winter and greater access to new green growth in spring, although quantity was reduced. The rested pasture provided more current-year forage, but the growth lacked nutritional quality equal to the 2 grazed pastures. Crane (2002) found that in winter and spring, elk preferentially selected feeding sites where cattle had grazed moderately during the previous summer, but in fall, elk selected sites where cattle use in summer had been light. Frisina (1992) successfully demonstrated a rest-rotation system designed to minimize elkcattle conflicts on summer range.

In developing a grazing system to provide improved nutritional forage quality to other herbivores, an important aspect is that during a 120- to 150 -day wintering period for wild ungulates, even small improvements in forage quality are physiologically important to animals (Albon and Langvatn 1992). Regrowth pastures, although compromised somewhat in forage production, provide high-quality forage that can serve as a supplement to adjacent pastures containing current-year growth of lesser quality. These improvements over untreated forage may be only marginally identified in research efforts, if only the percentage of crude protein in forage plants is measured, but their cumulative effects over the wintering period are significant. If the additional digestible energy and crude protein provided in conditioned plants during the wintering period are considered, then positive effects are more clearly identifiable. Given that winter range forages do not meet animal nutritional requirements and weight loss over the entire period is expected, any improvement in forage quality would mean less mobilization of body stores.

\section{Modifying Habitat Diversity}

Livestock do not graze rangelands or pastures uniformly. Preferred foraging areas are selected because of several characteristics (Bailey et al. 1996; Coughenour 1991). Likewise, other areas are avoided for another set of characteristics, at least until preferred areas are fully exploited and animals are forced to go elsewhere. This is a typical occurrence on many rangelands because of the physical characteristics of the landscape: steepness of slopes, limited water availability, or areas of nonpreferred forages. Vertical structure and canopy cover of the herb layer are modified by forage removal, creating a patchy landscape of varying height and cover, attributes listed by Payne and Bryant (1994) as important to wildlife. The size and extent of heavily grazed patches are merely functions of the number of livestock and the duration of use. The created patches, however, will probably persist because patch modification by grazing often enhances the desirability of that patch to the animal (McNaughton 1984). If major changes in patch size or location are required, then heavy grazing, prescribed fire, or changes in watering source may be in order to neutralize the created improved palatability of the grazed patches.

Just the presence of livestock may cause simple structural changes that benefit wildlife. In dense-wetland vegetation, cattle movement may open trails that then provide open water pathways for improved movement of waterfowl. Additionally, in habitat management for waterfowl, it is often desirable to set back succession and reduce monocultures of robust plants, to diversify monotypic plant communities with undesirable characteristics, to reduce woody vegetation in moist soil areas, and to modify vegetation structure (Cross 1988), all of which are possible with managed livestock grazing. Conversely, planned rest periods can provide sites of tall residual grass cover for waterfowl nesting (Kantrud 1990).

Livestock grazing may also create structural diversity (patchiness) of the herb layer as a desired edge effect for birds (Payne and Bryant 1994). Some birds, especially those that evolved in association with bison (Bison bison) grazing, such as mountain plover (Charadrius montanus) (Graul 1975), require bare ground for nesting. Payne and Bryant (1994) also noted that bare ground was important as feeding, nesting, dusting, and display sites for upland and passerine birds.

Morrow et al. (1996) described grazing as a tool to increase habitat diversity by the interspersion of open areas within grassland structure. These authors also suggested one contributing factor to a recent decline in Attwater's prairie chicken (Tympanuchus cupido attwateri) was insufficient livestock grazing. They also cited a US Fish and Wildlife Service (1993) report, which described livestock grazing as a tool to increase habitat heterogeneity for prairie chickens.

\section{IMPLEMENTATION}

Development and implementation of a prescription grazing plan to enhance or even maintain wildlife habitat is no simple task. An interdisciplinary approach is required that might include expertise in rangeland ecology, wildlife biology, and livestock production (Severson and Urness 1994). Although a given prescription may enhance a species of interest, other species may be unaffected or negatively affected. Additionally, a seasonal grazing prescription may have cascading effects on the livestock owner's operation.

\section{Rangeland Ecology}

Paramount to success of a prescription grazing plan is a thorough knowledge of the specific rangeland ecosystem and seral dynamics of each site within that system. Improving forage quality or enhancing forage yield sounds relatively easy when clipping studies (Pitt 1986; Ganskopp 1998) or small paddock studies (Riggs and Urness 1989; Ganskopp et al. 1999) are considered. Oftentimes, wetlands are composed of monotypic communities that provide little opportunity for cattle to exercise preference for individual forage species, foraging communities, or topographic characteristics so there is a high probability of restoration success with treatments. However, most treatments will be applied on a landscape scale across diverse plant communities of varying soil depth, slope, and aspect, which might react quite differently to a grazing treatment. Livestock use on those plant communities may also vary because of attributes of selection inherent to livestock (Bailey et al. 1996; Coughenour 1991). There may be extreme variation in vegetation response to grazing on disparate communities. For example, forage growing on deeper soil sites may respond well to spring grazing designed to provide regrowth of 
high nutritive value. In the same pasture, forage growing on shallower soil may not respond in a similar manner because of a lack of soil moisture available for regrowth.

In any grazing system designed to set back succession or favor a class of vegetation (shrubs), the threat of weed invasion or the increase of undesirable native species looms as a major deterrent to implementation. Intensive planning analysis and follow-up monitoring are requirements.

\section{Wildlife}

An intimate understanding of how target and nontarget species will be affected by grazing manipulations (Severson and Urness 1994 ) is also required in the planning process. Any habitat change made for a featured species may create adverse, neutral, or beneficial changes for other species (see Fagerstone and Ramey [1996] for positive, neutral, and negative grazing effects on various rodent species).

This concept produces an interesting conundrum for managers: how to improve habitat for a species of concern without destroying habitat for another species, which through habitat destruction may become a species of concern. Perhaps the answer lies in the "Modifying Habitat Diversity" section and the discussion of livestock use of landscapes. Landscape-size pastures, common in the semiarid West, commonly display patchiness from grazing use. The gradient may well go from ungrazed to $>60 \%$ use. Managing that diversity of utilization just may be the key to providing habitat for one species while preserving an entirely different habitat for another. As stated earlier, researchers commonly work at the plant-community level or at some other small scale. Experimental designs and treatment effects are much cleaner at small scales. However, management occurs at the landscape scale, and the application of small-scale research results to landscapes is often questionable and even resisted by managers. Landscape-level research that incorporates the concepts of Hobbs (1996) and Augustine and McNaughton (1998) on grazing as an enhancement of habitat diversity is needed.

\section{Livestock}

Integration of a prescription grazing system into the entire 12month operation of a livestock producer and that producer's understanding of the system are critical to successful implementation. In many cases, a grazing system may be implemented for a specific period (i.e., deer winter range or waterfowl nesting). If the system involves changing the traditional time of grazing, then impacts to the year-round operation occur. For example, to enhance production of bitterbrush, use can be shifted from late summer to spring to reduce use of bitterbrush and increase the use of grasses. However, the previously used spring range must also be compatible for fall use both in forage quality and the ease of livestock movement. The livestock producer should be involved in the planning process to ensure the management plan is compatible with the livestock operation. In some cases, a species of interest may occur throughout the producer's entire range, including private and public lands. In that case, coordinated management of all owners under one plan would be optimal (Frisina and Morin 1991).

Some prescription grazing systems may be designed for a special vegetation treatment that has the unwanted side effect of reduced livestock production. A careful analysis should be made before implementation to ensure the producer is aware of the consequences. For public land, some type of compensation or reduced grazing fees might be in order under those circumstances and would probably be necessary to entice a producer to participate. An example is winter grazing of dormant marsh vegetation for structure improvement for waterfowl. Forage quality would be low enough that the producer would incur increased supplementation costs.

On private lands, a system initiated by the landowner may, indeed, negatively impact livestock production. However, the private landowner's goal is usually to enhance a wildlife value that has marketability, and the increased income from that compensates for the reduced income from livestock.

\section{Additional Considerations}

A decision to develop a prescription grazing system may be made because a problem situation exists, such as elk use of private lands or poor waterfowl-nesting success. This is often accompanied by a change from little management to intensive management (Vavra and Sheehy 1996). Grazing management may go from continuous use, usually at too high of a level, to a grazing system. When the grazing system is developed, other improvements are often added, such as increased watering sites, reseeding, prescribed fire, and public-access control. Benefits to wildlife may not be totally related to the initiated grazing system; other activities in conjunction with the grazing system may be critical to success. Payne and Bryant (1994) concluded that nearly any grazing system was more beneficial to wildlife than continuous grazing. These authors provide an extensive list of grazing systems and their regional adaptability, effects on wildlife habitat, and comments of interest.

\section{CONCLUSIONS}

Today, livestock grazing systems, particularly on public lands, must be developed to meet current definitions of sustainability (Vavra 1996). Also, a healthy and diverse wildlife component is indicative of a healthy and diverse rangeland ecosystem, a credible goal regardless of specific interests (Severson and Urness 1994). In some cases, however, target species will constrain management of landscapes to provide for the benefit of that organism. In the past, the most common example of featured species management was big game winter-range designation. This usually occurred because winter-range conditions were unsatisfactory or big game was encroaching on private lands. There is still a definite need for managing land for big game ranges because habitats, particularly winter range, continue to shrink in the West. Both research data and case history demonstrations have been published on this topic. However, the real challenge is acting on a landscape scale when most research has come from individual plant and plant-community scales. Additionally, effects of these prescriptions on nontarget species need to be evaluated.

It is safe to assume that as public and government concern for biodiversity continues, more species of interest will be identified. At one time, there were 1258 species listed as threatened or endangered and 3000 being considered (US Fish and Wildlife Service 1992). Many of these species require 
rangeland habitat. Unfortunately, although species of interest are easily identified, there is little supporting data on optimum habitat. More than likely, research funds have not been available to provide a database for management, or it may be that, as in the case of sage-grouse, there is disagreement on the factors causing species decline or the potential remedial actions. The point is that the development of a grazing plan to benefit a species of interest may be more interpretation and art, and less the application of scarce science. We still need research on the effects of various livestock grazing systems on a landscape scale and on the structure and composition of plant communities and the organisms that inhabit those communities. That research could be accomplished with no single species requirement in mind, but researchers should quantify landscapescale vegetation structure, composition, standing crops, and nutritional quality attributes resulting from various grazing systems.

Severson and Urness (1994) found that the knowledge related to the use of livestock grazing as a tool to improve wildlife habitat was quite meager. The idea of using livestock as a tool for improving wildlife habitat was not new, but implementation into management practices was rare (Severson and Urness 1994). The situation today is not much better. In fact, more information is necessary just on the compatibility of grazing systems with wildlife. Almost all the research on this topic has involved species of "consumptive interest": those that are hunted, such as big game, quail, and waterfowl. There has been little interest in developing prescription grazing systems for nongame species.

There is reluctance by public land managers to show interest in livestock grazing for fear that the environmental community will see it as advocacy for the practice. Also, some professional wildlife biologists and wildlife interest groups have a definite bias against livestock (Knopf 1996; Severson and Urness 1994). However, if livestock continue to be grazed on public lands, it behooves managers to provide grazing systems that are compatible with the wildlife that share that environment and to provide viable economic return to livestock producers.

\section{LITERATURE CITED}

Albon, S. D., and R. Langvatn. 1992. Plant phenology and the benefits of migration in a temperate ungulate. Oikos 65:502-513.

Anderson, E. W., and R. J. Scherzinger. 1975. Improving quality of winter forage for elk by cattle grazing. Journal of Range Management 28:120-125.

Augustine, D. J., and S. J. McNaughton. 1998. Ungulate effects on the functional species composition of plant communities: herbivore selectivity and plant tolerance. Journal of Wildlife Management 62:1165-1183.

Balley, D. W., J. E. Gross, E. A. Laca, L. R. Rittenhouse, M. B. Coughenour, D. M. SwIFT, AND P. L. Sims. 1996. Synthesis paper: mechanisms that result in large herbivore grazing distribution patterns. Journal of Range Management 49: $386-400$.

Bryant, L. D. 1993. Quality of bluebunch wheatgrass (Agropyron spicatum) as a winter range forage for Rocky Mountain elk (Cervus elaphus nelsoni) in the Blue Mountains of Oregon [thesis]. Corvallis, OR: Oregon State University. $147 \mathrm{p}$.

CoughenouR, M. B. 1991. Spatial components of plant-herbivore interactions in pastoral, ranching, and native ungulate ecosystems. Journal of Range Management 44:530-542.

Crane, K. K. 2002. Influence of cattle grazing on feeding site selection by Rocky Mountain Elk [thesis]. Laramie, WY: University of Wyoming. 85 p.
Cross, D. H. 1988. Waterfowl management handbook. Washington, DC: US Fish and Wildlife Service. Leaflet 13.

CuRtin, C. G. 1994. Grazing and advocacy. Conservation Biology 9:233.

Evans, C. C. 1986. The relationship of cattle grazing to sage-grouse use of meadow habitat on the Sheldon National Wildlife Refuge [thesis]. Reno, NV: University of Nevada. $92 \mathrm{p}$.

Fagerstone, K. A., and C. A. Ramey. 1996. Rodents and lagomorphs, In: P. R. Krausman [ed.]. Rangeland Wildlife. Denver, CO: The Society for Range Management. p 83-132.

FleischneR, T. L. 1994. Ecological costs of livestock grazing in western North America. Conservation Biology 8:629-644.

FrISINA, M. R. 1992. Elk habitat use within a rest-rotation grazing system. Rangelands 14:93-96.

Frisina, M. R., And F. G. Morin. 1991. Grazing private and public land to improve the Fleecer Elk Winter Range. Rangelands 13:291-294.

GansKopP, D. 1998. Thurber needlegrass: seasonal defoliation effects on forage quantity and quality. Journal of Range Management 51:276-281.

Ganskopp, D., R. Angell, and J. Rose. 1992. Response of cattle to cured reproductive stems in a caespitose grass. Journal of Range Management 45: 401-404.

Ganskopp, D., T. Svejcar, F. Taylor, J. Farstvedt, and K. Paintner. 1999. Seasonal cattle management in 3- to 5-year-old bitterbrush stands. Journal of Range Management 52:166-173.

GoRdon, I. J. 1988. Facilitation of red deer grazing by cattle and its impact on red deer performance. Journal of Applied Ecology 25:1-10.

GraUL, W. D. 1975. Breeding biology of the mountain plover. Wilson Bulletin 87: 6-31.

HESS, M. 1975. Sage grouse and livestock grazing. In: W. A. Molini [ed.]. Transactions of the Ninth Biennial Western States Sage Grouse Workshop. Reno, NV. p 16-18.

HobBs, N. T. 1996. Modification of ecosystems by ungulates. Journal of Wildlife Management 60:695-713.

Huxtable, N. 1992. The desert tortoise. Rangelands 14(1):33-34.

Hyder, D. N., and F. A. Sneva. 1963. Morphological and physiological factors affecting the grazing management of crested wheatgrass. Crop Science 3: 267-271.

Jensen, M. N. 2001. Can cows and conservation mix? BioScience 51:85-90.

Jensen, C. H., A. D. Smith, ANd G. W. Scotter. 1972. Guidelines for grazing sheep on rangelands used by big game in winter. Journal of Range Management 25: 346-352.

KantRud, H. A. 1990. Effects of vegetation manipulation on breeding waterfowl in prairie wetlands: a literature review. In: K. E. Severson [ed.]. Proceedings of the Society of Range Management symposium: Can livestock be used as a tool to enhance wildlife habitat? Fort Collins, C0: Rocky Mountain Forest and Range Experiment Station. General technical report RM-194. p 93-123.

Knopf, F. L. 1996. Perspectives on grazing nongame bird habitats. In: P. R. Krausman [ed.], Rangeland wildlife. Denver, CO: The Society for Range Management. p 51-58.

Leopold, A. 1933. Game management. New York, NY: Charles Scribner's Sons. $481 \mathrm{p}$.

Lesperance, A. L., P. T. Tueller, and V. R. Bohman. 1970. Competitive use of the range forage resource. Journal of Animal Science 30:115-120.

McNaughton, S. J. 1984. Grazing lawns: animals in herds, plant form, and coevolution. American Naturalist 124:863-886.

Morrow, M. E., R. S. Adamcik, J. D. Friday, and L. B. McKinney. 1996. Factors affecting Attwater's prairie-chicken decline on the Attwater Prairie Chicken National Wildlife Refuge. Wildlife Society Bulletin 24:593-601.

NeAL, D. L. 1982. Improvement of Great Basin winter range with livestock grazing. In: J. M. Peek and P. D. Dalke [eds.] Wildlife-livestock relationships symposium proceedings, Moscow, ID: University of Idaho. p 61-73.

Payne, N. F., and F. C. Bryant. 1994. Techniques for wildlife habitat management of uplands. New York, NY: McGraw-Hill, Inc. 840 p.

Peterson, J. G. 1970. The food habits and summer distribution of juvenile sage grouse in central Montana. Journal of Wildlife Management 34:147-155. 
PItT, M. D. 1986. Assessment of spring defoliation to improve fall forage quality of bluebunch wheatgrass (Agropyron spicatum). Journal of Range Management 39:175-181.

ReIneR, R. J., ANd P. J. URness. 1982. Effect of grazing horses managed as manipulators of big game winter range. Journal of Range Management 35:567-571.

RHOdES, B. D., AND S. H. SHARRow. 1990. Effect of grazing by sheep on the quantity and quality of forage available to big game in Oregon's Coast Range. Journal of Range Management 43:235-237.

Riggs, R. A., AND P. J. URness. 1989. Effects of goat browsing on Gambel oak communities in northern Utah. Journal of Range Management 42:354-360.

Severson, K. E., and P. J. Urness. 1994. Livestock grazing: A tool to improve wildlife habitat. In: M. Vavra, W. A. Laycock, and R. D. Pieper [eds.] Ecological implications of livestock herbivory in the West. Denver, CO: Society for Range Management. p 232-249.

Smith, A. D. 1949. Effects of mule deer and livestock upon a foothill range in northern Utah. Journal of Wildlife Management 13:421-423.

Smith, A. D., AND D. D. DoelL. 1968. Guides to allocating forage between cattle and big game on big game winter range. Salt Lake City, Utah: Utah State Division of Fish and Game. Publication 68-11.

[USFWS] United States Fish and Wildlife Service. 1992. Report to Congress: endangered species recovery program. Washington, DC: United States Department of the Interior. $270 \mathrm{p}$.

[USFWS] United States Fish and Wildlife Service. 1993. Attwater's prairie chicken recovery plan. Albuquerque, NM: United States Department of the Interior. $48 \mathrm{p}$.

URNESS, P. J. 1990. Livestock as manipulators of mule deer winter habitats in northern Utah, In: K. E. Severson [ed.]. Can livestock be used as a tool to enhance wildlife habitat? Fort Collins, CO: United States Forest Service. General technical report RM-194. p 25-40.

VavRA, M. 1996. Sustainability of animal production systems: an ecological perspective. Journal of Animal Science 74:1418-1423.

VAVRA, M. 1998. Public land and natural resource issues confronting animal scientists and livestock producers. Journal of Animal Science 76: 2340-2345.

VavRA, M., And D. P. SheEHy. 1996. Improving elk habitat characteristics with livestock grazing. Rangelands 18:182-185.

Westenskow-Wall, K. J., W. C. Krueger, L. D. Bryant, and D. R. Thomas. 1994 Nutrient quality of bluebunch wheatgrass regrowth on elk winter range in relation to defoliation. Journal of Range Management 47:240-244.

Wisdom, M. J., AND J. W. Thomas. 1996. Elk. In: P. R. Krausman [ed.]. Rangeland wildlife. Denver, C0: Society for Range Management. p 157-181. 